female-friendly agenda in giving her protagonists agency in love and selfawareness and avoiding the victimization of falling prey to gender traps.

Julia Kisacky's translation is both accurate and eminently readable, altering word order and punctuation for those purposes. Very detailed notes make its classical references easy to follow. It takes its place beside Campbell's as another lively, witty treatment of a valuable text that is deserving of this additional scholarly attention to further solidify Andreini's enduring genius.

ROSALIND KERR

University of Alberta

\title{
Bartlett, Kenneth.
}

Florence in the Age of the Medici and Savonarola, 1464-1498: A Short History with Documents.

Indianapolis: Hackett Publishing Company, 2018. Pp. xv, 176. ISBN 978-162466-681-0 (paperback) US\$18.

Sourcebooks and textbooks are always welcome; indeed, there are too few such publications available for those who teach the history of Renaissance Florence and Italy to English-speaking students. Kenneth Bartlett's compact publication perfectly fits the purpose, not least because of its reasonable price and the explanatory glossary at the end. The time frame encompassed by the book is rather narrow and includes only a very limited part of the Medici rule in Florence, and thus of the Renaissance period, but this is justified by the fact that those years were extraordinarily intense and eventful. The text is divided into two parts of similar length: an introduction to the historical context and a series of thirty-two primary sources translated into English.

In the first part, Bartlett does an excellent job of illustrating events and issues relevant to the historical period. His introduction is divided into three chapters: the first, and shortest, contains an overview of the previous period, from the disputes between the Guelfs and Ghibellines to the Ciompi revolt in 1378. The second and longest chapter is devoted to the Medici hegemony from 1434 to 1494 and illustrates their rise and (temporary) fall, mostly focusing on political and cultural developments. The third and final chapter deals with the Savonarolan years (1494-98) and outlines the features and contradictions 
of a unique moment in history. The three chapters succeed in placing the history of Renaissance Florence in a broader geographical and chronological context, not only by explaining how the rise of the Medici family was possible but also by illustrating the dynamics that linked the Republic of Florence to other Italian and non-Italian states. As is well known, Quattrocento Florence was characterized by an apparent respect for republican institutions and the struggle to exert control over them, and by de facto rulers who paid lip service to republican ideology. It was a context in which, in the absence of hereditary legitimacy, access to (and the maintenance of) political power was determined by other factors, such as wealth, self-representation, moral authority, charisma, and propaganda. Bartlett skilfully illustrates and analyzes the gradual transformation of Florence "from a managed republic to a clandestine principality" (42). Several cross-topics are well delineated throughout the text, such as the coexistence of spiritual and pagan elements, the tension between private interest and civic values, and the shifting balance between powers and counter-powers. The style is very clear, the narrative is effectively structured, and the text, while avoiding oversimplification, is easily accessible.

Unlike the first part, the documentary section of the book is not entirely satisfactory because of both its content and the way it is structured. First, I must say I was somewhat disappointed that nearly all the primary sources (twentyeight out of thirty-two) have already been published not only in Italian but also in English translation. In this respect, the book is not a significant addition to our current patrimony of translated texts. Seventeen documents are taken from only five books-classical publications that most Anglophone scholars of Renaissance Florence will already have in their libraries. Second, the documents only come with a very short introduction and lack any type of explanatory notes. Unfortunately, readers who wish to gain a better understanding of the people and events mentioned in the texts are not given much help. Third, the order and chronology of the primary sources are not unproblematic. It is not clear why the documents are not in chronological order (or, apparently, in any other kind of order) and why several of them exceed the time span of the book (at least six of them date back to before the year 1464); for Document 25 (146-47) it is impossible to get the slightest idea of the period (even the century) in which it was created. And, when indicated, the date it is not always correct: Document 29 (154-57) refers not to the 1497 Bonfire of the Vanities but to the one in 1498, 
as is clearly indicated in both the text itself and in the modern book from which the source is taken.

Despite its shortcomings, this a very useful book overall. The brilliant first part provides an enjoyable and informative introduction to the subject for English-speaking readers, while the documents in the second part, leaving aside the above-mentioned issues, represent an excellent selection to give the students an overview of the period and its significance. The sources show how Renaissance Florence's extraordinary historical players, such as Cosimo and Piero de' Medici, Lorenzo the Magnificent, and Girolamo Savonarola, were perceived by their contemporaries. The wide range of different kinds of documents, such as chronicles, letters, diaries, and sermons, is ideal for students who want to get a glimpse of what and how fifteenth-century people used to write.

STEFANO DALL'AgLio

The Medici Archive Project, Florence

\section{Bassnett, Madeline.}

\section{Women, Food Exchange, and Governance in Early Modern England.}

Early Modern Literature in History. New York: Palgrave Macmillan, 2016. Pp. ix, 248. ISBN 978-3-319-40867-5 (hardcover) €88.39.

Women, Food Exchange, and Governance in Early Modern England examines a nexus of concerns that scholars are just beginning to explore: women's writing in Renaissance England; the politics of food and agriculture; and the roles of women in household, local, regional, and national governance. Focusing mostly upon the Stuart period, Madeline Bassnett, an associate professor at Western University, shows how these three areas of study are closely related, and how beneficial it is to study them in tandem. The monograph draws together concerns about authorship, selfhood, food, gift-giving, and the performance of authority into a forceful argument for the importance of attending to all these issues. The book makes a lucid case for "illuminat[ing] not only constructions of female subjectivity but also women's relationship to social, religious, and political networks" (6). As such, it both joins an ongoing conversation about 